\title{
Molecular Genetics of Gerstmann-Sträussler-Scheinker Disease and Creutzfeld-Jakob Disease
}

\section{Pawel P Liberski* and Witold K Surewicz ${ }^{2}$}

${ }^{1}$ Department of Molecular Pathology and Neuropathology, Medical University of Lodz, Lodz, Poland

${ }^{2}$ Department of Physiology and Biophysics, Case Western Reserve University, Cleveland, Ohio, USA

\begin{abstract}
Prion diseases are a group of transmissible neurodegenerative disorders associated with the misfolded form of

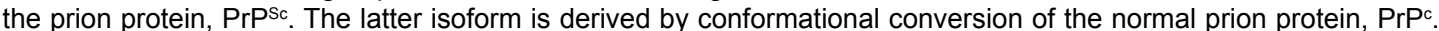
The gene encoding the prion protein is highly conserved among species. There are several distinct types of prion diseases in humans: kuru, Creutzfeldt - Jakob disease (CJD), Gerstmann-Sträussler-Scheinker disease (GSS) and Fatal Familial Insomnia (FFI) and its sporadic analogue, fatal sporadic insomnia. While human prion diseases are mostly sporadic, some $15 \%$ of CJD and all cases of GSS are hereditary disorders caused by mutations in the PRNP gene. There are two major types of mutations in PRNP: point mutations leading to amino acid substitutions and mutations leading to expansions of the octapeptide repeat region within the $\mathrm{N}$-terminal part of the prion protein. This review describes different types of familial prion diseases linked to specific polymorphisms and mutation in $P R N P$.
\end{abstract}

Keywords: Prion diseases; Familial prion diseases; Creutzfeldt jakob disease; Gerstmann-straussler-scheinker disease

\section{Key Concepts}

- Prion diseases are associated with the conformational conversion of a normal prion protein $\left(\mathrm{PrP}^{\mathrm{C}}\right)$ into a misfolded form, $\operatorname{PrP} \mathrm{Pc}^{\mathrm{sc}}$

- While the majority of CJD cases are sporadic, there are also familial forms

- All cases of GSS are hereditary

- Familial prion disease are caused by mutations in the gene encoding the prion protein

\section{Introduction}

Prion diseases, or Transmissible Spongiform Encephalopathies (TSEs), are a group of neurodegenerative disorders which include kuru, Creutzfeldt-Jakob Disease (CJD), Gerstmann-Sträussler-Scheinker Disease (GSS), and Fatal Familial Insomnia (FFI) and its sporadic analogue, fatal sporadic insomnia, in humans; natural scrapie in sheep and goats; Bovine Spongiform Encephalopathy (BSE) in cattle; Chronic Wasting Disease (CWD) in cervids; and Transmissible Mink Encephalopathy (TME) in ranch-reared mink. Variable ProteaseSensitive Prionopathy (VPSP) is a new disease described recently by Gambetti et al. [1] the majority of human prion diseases are sporadic, but there are also familial forms. Some of the latter were recognized long before the era of the 'protein-only' model of prion diseases and molecular genetics [2], as exemplified by the famous case of a disease in the Backer family [3].

\section{Nomenclature}

The normal form of the prion protein is known as $\operatorname{PrP}^{c}(c$, from "cellular"). The misfolded, disease-associated isoform is typically denoted $\operatorname{PrP}^{\mathrm{Sc}}$ (Sc, from scrapie, a prion disease of sheep). The PrPsc isoform has been classically considered equivalent to the aggregated form of the prion protein that is partially resistant to proteinase $\mathrm{K}$ (PK) digestion [1]. However, the situation is complicated by recent data showing that there may also be disease-associated forms of the prion protein that are susceptible to proteolytic degradation. Nevertheless, it is convenient to classify different forms of prion diseases according to the presence of particular types of $\mathrm{PrP}^{\mathrm{Sc}}$ aggregates as defined by the $\mathrm{PK}$ digestion pattern.

\section{Prp, Its Gene PRNP, and the "Prion Hypothesis"}

$\operatorname{PrP}^{\mathrm{c}}$ is encoded by a gene mapped to chromosome 20 in humans and chromosome 2 in mice [4]. The gene (PRNP in humans) is ubiquitous and highly conserved; it has been cloned in numerous mammalian species, included marsupials, and there are analogues of this gene in birds, reptiles, amphibians, and fish; the latter posseses two $\operatorname{PrP}$ genes, PrP1 and PrP2 [5]. Upon processing that removes 22 amino acids from the $\mathrm{N}$-terminus and 23 amino acids from the $\mathrm{C}$-terminus, the mature human $\operatorname{PrP}^{\mathrm{C}}$ is a 209 amino acid long protein containing two potential sites for N-linked glycosylation (Asp 181 and Asp 197) and a C-terminal glycophosphatidylinositol (GPI) anchor that tethers the protein to the outer surface of the plasma membrane. The central event in the pathogenesis of TSE diseases is the conversion of $\operatorname{PrP}^{\mathrm{C}}$ to $\operatorname{PrP}^{\mathrm{Sc}}$. In contrast to a largely $\alpha$-helical and monomeric $\operatorname{PrP}^{\mathrm{C}}$ that is readily degraded by proteolytic enzymes, $\mathrm{PrP}^{\mathrm{Sc}}$ is a protein aggregate that is rich in $\beta$-sheet structure and possesses a characteristic proteinaseresistant core region. In 1982, Prusiner proposed that $\operatorname{PrP}^{S c}$ itself represents the infectious the infectious agent causing TSE diseases [6]. Once revolutionary and highly controversial, this 'protein-only' model is now supported by wealth of experimental data, [7-9] most notably the recent success in generating infectious prions in vitro from highly purified prion protein [10]. Thus, the notion that misfolded proteins can be "infectious" has emerged as a new paradigm in molecular biology and medicine.

One of the characteristic features of human $\operatorname{PrP}^{\mathrm{C}}$ is the methionine/ valine (Met/Val) polymorphism at codon 129. Furthermore, two types of major PK-resistant $\mathrm{PrP}^{\mathrm{Sc}}$ fragments are observed in sporadic CJD cases (Figure 8). One of them is characterized by electrophoretic mobility (for an unglycosylated form) of $21 \mathrm{KDa}$ (type 1) and another one of $19 \mathrm{kDa}$ (type 2), suggesting different $\mathrm{PrP}^{\mathrm{Sc}}$ conformations.

*Corresponding author: Pawel P Liberski, Department of Molecular Pathology and Neuropathology, Medical University of Lodz, 8/10 Czechoslowacka St., 92-216 Lodz, Poland, Tel/fax: 484267914 77; E-mail: ppliber@csk.umed.lodz.pl

Received April 06, 2013; Accepted June 19, 2013; Published June 24, 2013 Citation: Liberski PP, Surewicz WK (2013) Molecular Genetics of GerstmannSträussler-Scheinker Disease and Creutzfeld-Jakob Disease. Genetics 2: 117 doi:10.4172/2161-1041.1000117

Copyright: (c) 2013 Liberski PP, et al. This is an open-access article distributed under the terms of the Creative Commons Attribution License, which permits unrestricted use, distribution, and reproduction in any medium, provided the original author and source are credited. 
The combination of the status of codon $129 \mathrm{Met} / \mathrm{Val}$ genotypes with these two distinct $\operatorname{PrP}^{\mathrm{Sc}}$ conformers provides a basis for phenotypic classification (or 'strain' variability) of sporadic CJD diseases [11]. The combinantion of codon $129 \mathrm{Met} / \mathrm{Val}$ with specific mutations in PRNP is also the major determinant of strain variability in familial prion diseases. In this article, we briefly review different forms of human prion disorders associated with these individual mutations.

\section{Silent Polymorphisms}

There are several silent polymorphisms within OFR (open frame of reading, a gene sequence encoding for a protein) of the PRNP gene

$$
\begin{aligned}
& \text { Pro68Pro }(\mathrm{CCT}=>\mathrm{CCC}) \\
& \text { Ala117Ala }(\mathrm{GCA}=>\mathrm{GCG}) \\
& \text { Gly124Gly }(\mathrm{GGC}=>\mathrm{GGG}) \\
& \text { Val161Val }(\mathrm{GTG}=>\mathrm{GTA}) \\
& \text { His177His }(\mathrm{CAC}=>\mathrm{CAT}) \\
& \text { Glu212Glu }(\mathrm{CAG}=>\mathrm{CAA}) \\
& \text { Arg228Arg }(\mathrm{AGA}=>\mathrm{AGG}) \\
& \text { Ser230Ser }(\mathrm{TCG}=>\mathrm{TCA})
\end{aligned}
$$

\section{Familial CJD}

\section{The codon $178^{\text {Asp }} 129^{\mathrm{Val}}$ mutation}

Goldfarb et al. [12] found a mutation in codon 178 within the PRNP gene in a large Finnish family with CJD. A G to A mutation at codon 178 was found resulting in an Asn to Asp substitution. This mutation was found in several families included the famous Backer family in which hereditary CJD was first described. It manifests clinically as otherwise typical CJD, but onset is earlier and there are no typical periodic EEG and myoclonic jerks.

\section{Fatal Familial Insomnia}

\section{The codon $178^{\text {Asp }} 129^{\text {Val }}$ mutation}

The same mutation but coupled with $129^{\text {Met }}$ is linked to Fatal Familia Insomnia (FFI) [13]. The phenotype consists of sleep disorders, nocturnal hallucinations, behavioral disturbances and autonomic dysfunctions. Neuropathologically, changes are confined to the thalamus and aggregates of $\mathrm{PrP}^{\mathrm{Sc}}$ may be focal and very limited.

\section{The codon $180^{\text {Iso }} 129^{\text {Met }}$ mutation}

The age of onset varied between 66 and 85 years while duration between 1 and 2 years [14-17]. Phenotypically it is a typical CJD except for the lack of periodic EEG in the majority of cases. Pathological laughing and crying was suggested as a characteristic symptom. MRI demonstrated signal hyperintensity in cortical and subcortical location.

\section{The codon $183^{\text {Val }} 129^{\text {Met }}$ mutation}

This mutation is characterized by Parkinsonism and dementia similar to the frontotemporal dementias. Neuropathology included spongiform change $[18,19]$.

\section{The codon $188^{\text {Arg (Ala or Lys) }} 129^{\text {Val or Met }}$ mutation}

Phenotypically, the $188^{\text {Lys }}$ mutation manifested in a 59 -year-old patient as a rapidly progressive dementia, and dysphasia. The case of $188^{\text {Arg }}$ was a 55 -year-old man with behavioral disturbances, dementia, some leg dysmetria and sensory changes; inconclusive 14-3-3 in the CSF and MRI scan revealed hyperintensity in the cortical ribbon, putamen and caudate. Neuropathology was typical for CJD with some balloon neurons. The EEG demonstrated either periodic pattern or diffuse slowing. The case $188^{\mathrm{Ala}}$ was an 82 -year-old woman with typical periodic EEG and positive 14-3-3 in the CSF [20,21].

\section{The codon $193^{\text {Iso }} 129^{\mathrm{Val}}$ mutation}

This was a 70-year-old case with gait disturbances, behavioral problems and dementia, Babinski sign and myoclonus. There was typical periodic EEGand CSF was positive for the presence of the 14-3-3-protein [22].

\section{The codon $196^{\mathrm{Lys}} 129^{\mathrm{Met}}$ mutation}

This mutation is characterized by rapidly progressive dementia with no periodic EEG. The age of onset is between 63 and 77 years; duration less than 1 year [23].

\section{The Association of CJD Cases of Eastern European Origin and in Sephardic Jews: Mutation; The Codon $200^{\text {Lys }} 129^{\text {Met }}$ Mutation}

The codon 200 mutation is associated with a Glu to Lys substitution. Several healthy individuals from affected families at the risk for CJD were tested positive for the presence of the 200 codon mutations. The latter finding is of utmost interest, suggesting that the mutation itself is not sufficient for the development of the disease (or that penetration of this mutation-linked disease is not complete).

The phenomenon of CJD clustering among Libyan Jews have been known for several years, but the clinical features of CJD cases of Libyan origin did not differ significantly from those of sCJD cases of different origin. An extensive search for the putative iatrogenic factors responsible for the high frequency of CJD in this population has been published [24]. Particularly, the high proportion of brain consumption (79 to $92 \%$ of CJD cases) was found but frequency of this phenomenon did not differ significantly from that encountered among control subjects. It is noteworthy that brains were consumed as stew (m'chuma), patty (makod) or slightly (5 minutes) grilled.

The clinical phenotype had been studies for more than 20 years [ 25 30]. The age of onset varied between 35 and 66 years and the duration between 35 and 66 years. The picture is consistent with otherwise typical sporadic CJD except that occurrence of progressive supranuclear palsy and peripheral neuropathy was described. Fasciculations were noticed. EEG revealed periodic pattern. The haplotype $200^{\mathrm{Lys}} 129^{\mathrm{Val}}$ is characterized by a different phenotype [31] which consists of plaquelike PrP deposits and type $2 \mathrm{PrP}^{\mathrm{Sc}}$.

\section{The codon $203^{\text {Iso }} 129^{\text {Met }}$ mutation}

The disease started at the age 69 and lasted approximately 1 year [32]. Phenotype corresponded to otherwise typical CJD.

\section{The codon $208^{\mathrm{Arg}} 129^{\mathrm{Met}}$ mutation}

The age of onset is 69 [11]. Phenotypically this is a typical CJD with myoclonic jerks and periodic EEG.

\section{The codon $208^{\mathrm{His}} 129^{\mathrm{Val}}$ mutation}

This was a 61-year-old woman with behavioral disturbances, dementia, rigidity, no myoclonic jerks and progressive supranuclear palsy syndrome $[33,34]$. 


\section{The codon $210^{\text {Iso }} 129^{\text {Met }}$ mutation}

Phenotypically this is a typical CJD; disease started between 49 and 70 years of age and lasted between 3 - 5 months [35-37].

\section{The codon $211^{\text {Iso }} 129^{\text {Met }}$ mutation}

Phenotypically this is a typical CJD with periodic EEG; disease started between 42 and 81 years of age and lasted between $3-32$ months [38].

\section{The codon $226^{\text {STOP }} 129^{\text {Met Val }}$ mutation}

One case in a 55-year-old woman with cognitive impairment, acoustic and visual hallucination, myoclonic jerks and eventually akinetic mutism was described [39]. The major finding was a diffuse amyloid $\mathrm{PrP}^{\mathrm{Sc}}$-angiopathy (Figure 1) accompanied by synaptic $\mathrm{PrP}^{\mathrm{Sc}}$ deposits. Focal MAP-tau deposits were present around blood vessels.

\section{The codon $232^{\mathrm{Arg}} 129^{\mathrm{Met}}$ mutation}

This is an interesting mutation as it is not only linked to two different phenotypes of familial CJD syndromes but also mutation at this codon is linked to the GSS. FCJD with this mutation is either "slow" or "fast" in regard to duration of the disease. The onset is from 50 to 70 years; EEG showed a typical periodic pattern and a test for 14-3-3 is positive [40-43].

\section{Octarepeat Expansions}

In the region $51-91$ of the PRNP gene there are four perfect octarepeats (R1, R2, R2, R3, R4) of sequence Pro-His-Gly-Gly-Gly-(Gly)-Trp-Gly-Gln and 1 pseudoreapet in which His is replaced with Gln. The His-Gly-Gly-Gly-Trp peptide is in a $\beta$-turn conformation wrapped around a copper iron [44]. This region is not a part of $\mathrm{rP} 27-30$ and the mechanisms by which octapeptide expansions lead to CJD or GSS is unknown.

\section{Additional Repeats [45]}

1 octapeptide (repeat 24 bp insert, 129 ${ }^{\mathrm{Met}}$ ) (R1 R2 R2 R2 R3 R4 or R1 R2 R2 R3g_R3 R4) Age of onset, 58 - 73 years; duration, 4 10 months. Typical CJD phenotype with myoclonic jerks and periodic EEG pattern. R4)

2 octapeptides (repeat 48 bp insert) (R1, R2, R2, R3, R2a, R2a,

$129^{\text {Met }}$, age of onset, 58 years; duration, 3 months. Typical CJD phenotype with myoclonic jerks and periodic EEG pattern; $129^{\mathrm{Val}}$, dementia and ataxia, more like GSS
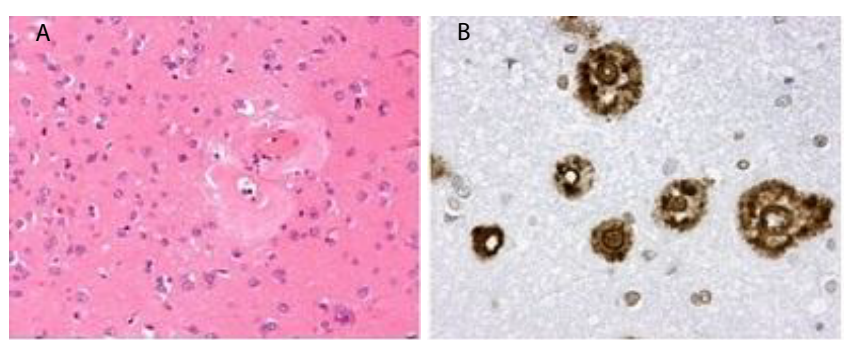

Figure 1: PrP-amyloid angiopathy in a case of the codon $226^{\text {sToP }} 129^{\text {Met Val }}$ mutation

A: $H$ \& $E$

B: PrP immunohistochemistry. Courtesy, of Dr. C. Jansen, Klinisch Patholoog Stichting Laboratorium Pathologie Oost-Netherlands.
4 octapeptides (repeat 96 bp insert) (R1, R2, R2, R2, R2, R2, R2, R3, R3)

$129^{\mathrm{Met}}$, age of onset, $56-65$ years; duration, 2 months -7 years. CJD-like phenotype; $129^{\mathrm{Val}}$, age of onset, 82 years; duration, 4 months. CJD-like phenotype.

5 octapeptides (repeat 120 bp insert $\left.1^{\text {et }}\right)(\mathrm{R} 1, \mathrm{R} 2, \mathrm{R} 2, \mathrm{R} 3, \mathrm{R} 2$, R2, R3, R3, R3, R4)

Age of onset, 26 - 61 years; duration, 4 - 19 months. Typical CJD but with long duration of disease, up to 14 years and personality changes observed since early childhood; $129^{\mathrm{Val}}$, age of onset, 46 years; duration, 4 months.

6 octapeptides (repeat 144 bp insert $129^{\mathrm{Met}}$ ) (inserts: R1, R2, R2, R2, R3, R2, R3g, R2, R2, R3, R4 or R1, R2, R3, R2, R2, R3g, R2, R3g, R2, R3, R4 or R1, R2, R2, R2, R2, R2, R2, R2, R2, R3, R4)

Age of onset varies between 22 and 53 years and the disease lasts from a few to 15 years. Clinically, CJD-like phenotype, dementia and focal signs, including the Babinski sign, are the main signs and symptoms. Characteristic are premorbid personality and behavioral changes, noticed even in nearly childhood as aggression, rapid mood changes, antisocial and criminal behavior and hypersexuality. Severe myoclonic jerks are typical. No periodic pattern of EEG was observed. Neuropathologically, linear deposits of $\mathrm{PrPs}^{\mathrm{sc}}$ situated perpendicularly to the cerebellar surface and kuru plaques in a single case were observed. Another case of a GSS phenotype in a 65-year-old woman was recently described [46] (Figure 2). The spongiform change was widespread and kuru-like and multicentric plaques were seen in the cerebellar cortex. The sequence of repeats was: R1, R2, R2, R3, R2, R3g, R2, R2, R2, R3, R4. The $\operatorname{PrP}^{\mathrm{Sc}}$ was of $7 \mathrm{kDa}$ species. Still another case was described by Gelpi et al. [47].

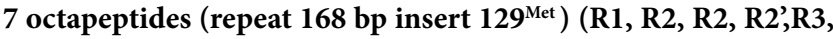
R2, R3, R3, R2, R3, R2", R3, R4). Age of onset, 25 - 35 years; duration, 7 - 16 months. This family presented a CJD-like phenotype with dementia, myoclonic jerks and extrapyramidal signs and symptoms.

8 octapeptides (repeat 192 bp inserts $129^{\mathrm{Met}}$ or $129^{\mathrm{Val}}$ ) (R1, R2, R2, R3, R2, R2, R2, R2, R2, R2, R2, R2q, R4)

Age of onset, 21 - 34 years; duration, 12 months - 7 years. Some families are characterized by heterogeneity of signs and symptoms from CJD-like with periodic EEG to GSS-like disease. Numerous amyloid multicentric plaques. $129^{\mathrm{Val}}$, numerous multicentric plaques; GSS-likephenotype.

9 octapeptides (repeat 216 bp insert $\left.129^{\text {et }}\right)(\mathrm{R} 1, \mathrm{R} 2, \mathrm{R} 2, \mathrm{R} 3, \mathrm{R} 2$, R3, R3g, R2, R2a, R2, R3, R2, R3, R4)

Age of onset, 32 - 55 years; duration, 2 to more than 4 months.

\section{Gerstmann-Sträussler-Scheinker Disease}

Gerstmann-Sträussler-Scheinker Disease (GSS) is a slowly progressive hereditary autosomal dominant neurodegenerative disease. It is the first human prion disease in which a mutation was discovered, establishing a solid link between the prion protein and these neurodegenerative disorders. GSS diseases are very rare, with the prevalence in the range of 1-10 per million [45].

According to Budka et al. [48] GSS is defined as a neurodegenerative disease "in family with dominantly inherited progressive ataxia and/or dementia: encephalo(myelo)pathy with multicentric PrP plaques".

The original Austrian " $\mathrm{H}$ " family had been known in Vienna since 

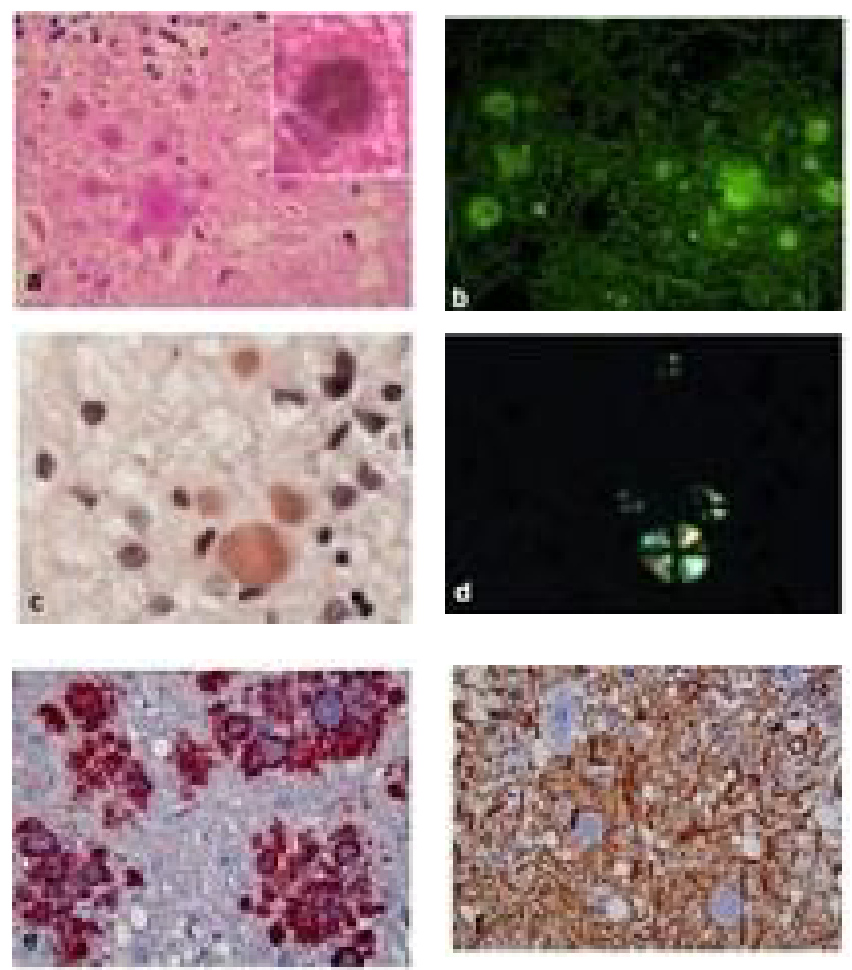

Figure 2: Amyloid plaques from a case of six octarepeats insertions [46]. Courtesy of Dr. Anne Vital, Victor Segalen-Bordeaux 2 University, Institute of Neurodegenerative Diseases, Bordeaux, France

A: $H \& E$

B: Thioflavine S

C: Congo red

D: birefringence

E: anti PrP

F: GFAP staining

the $\mathrm{XX}^{\text {th }}$ century and was reported by Dimitz in 1913, [49] then by Gerstmann in 1928 [50] and again by Gerstmann et al. in 1936 [51]. In the 1936 original paper, the first name of Scheinker, Isaak, was replaced by the initial "I". In Austria merely 3 years before Nazi takeover, it was risky to admit a Jewish extraction. Later on, Scheinker emigrated to the U.S. where he became a well known neuropathologist, who published, among other works, "Neuropathology In Its Clinicopathologic Aspects" [52].

Subsequent members of the same family were described by von Braunmühl [53] and Franz Seitelberger [54,55] Seitelberger, four years before the discovery of the transmissible nature of kuru by Gajdusek et al. [56] stressed the close neuropathological similarity in a form of amyloid plaques of kuru and GSS and in a sense "preconceived" the transmissible nature of GSS [57]. The history of original GSS " $\mathrm{H}$ " family from Vienna is interesting. This family originated from a small rural town in the lower Austria and had been diagnosed by local doctors as suffering from hereditary neurosyphilis. As this diagnosis stigmatized them, they decided to hide from doctors. In 1990, Professor Herbert Budka consulted on a female case suspected of CJD whose father died with a diagnosis of "Friedreich ataxia". The maiden name of this case " $\mathrm{H}$ " was the name of the GSS family [58,59]. This discovery enabled modern studies of those fascinating kindred.

Several GSS cases belonging to a few then well-known families were described as transmissible to non-human primates [57]. The Fujisaki strain of GSS (codon 102 mutation) first isolated by Tateishi et al. [60] was passaged to mice, rats, guinea pigs and Squirrel monkeys. Another case with the same mutation [61] was passaged to Spider monkeys. This passage was later confirmed by transmission to Marmosets [62]. To date, only inocula derived from 5 brains with $102^{\text {Leu }}$ transmitted [63].

\section{The codon $102^{\text {Leu }} 129^{\text {Met }}$ mutation}

At codon 102, a mutation leading to a substitution of Pro (CCG) by Leu (CTG) was found [64]. This mutation was subsequently found in several families from Japan [65-71], Germany [72,73] - in the well described Sch. family [74-77], Israel [78], Hungary [79], Poland [80], UK $[81,82]$, Italy [83-85] and in the original Viennese " $\mathrm{H}$ " family [86]. Japanese cases are interesting, as before the era of molecular biology they were regarded as CJD cases with abundant plaques [87] while in reality these were GSS cores.

The original family from which 4 cases were described by Seitelberger [55] numbered then 81 members; currently the genealogical tree was expanded to 221 member including 20 definitive GSS cases [58]; no update exists, Hainfellner - personal communication]. As in other GSS families linked to the 102 codon mutation, the disease manifests as slowly progressive cerebellar ataxia with dementia appearing late in the course of disease. The last case of GSS from this family (children of her were tested for a mutation and proved negative for the codon 102 mutation) exhibited, however, features of otherwise typical CJD - i.e. early symptoms of dementia and a characteristic periodic EEG.

For some GSS families with the 102 codon mutation, a typical feature is heterogeneity of neurological signs and symptoms. The classical ataxic type starts in second to sixth decade and the duration of the disease ranges from a few months to a few years. Ataxia, dysartria, and disturbances of saccadic eye movements, pyramidal and extrapyramidal signs and symptoms and cognitive changes leading to frank dementia have been listed among typical features. The latter leads, in a terminal phase of the illness, to the stage of akinetic mutism. Sympathetic hyperactivity and parasympathetic hypoactivity, similar to those encountered in FFI were reported [88]. Hyperthermia, tachycardia and hyperhidrosis were observed. In a proportion of cases, a CJD-like disease type with myoclonic jerks and periodic EEG pattern is observed. In those cases, the accelerated course leading to death in 5-9 months, also typical for sCJD, is seen.

A separate issue is the status of the codon 129 in combination with a mutated codon 102 . In the vast majority of GSS cases with the codon 102 mutation, $129^{\text {Met }}$ is observed on a mutated allele $[64,73,89$ 91]. Cases coupled with $129^{\mathrm{Val}}$ are rare. A case described by Young et al. [92] was a 33-year-old male, clinically significantly different from those of $129^{\mathrm{Met}}$, by the presence of seizures as a initial sign, lower limb paraesthesias and bilateral deafness but not dementia.
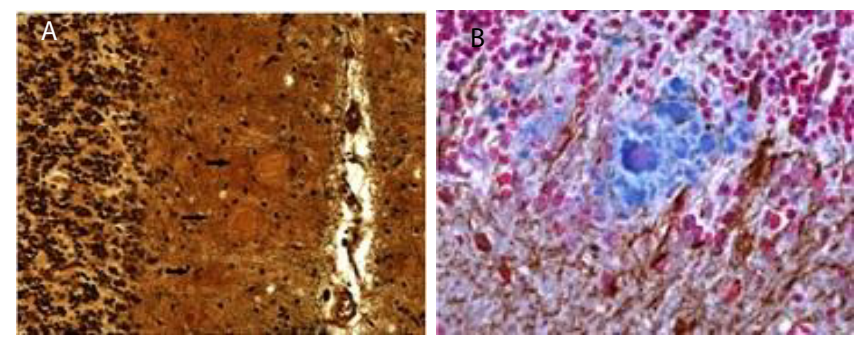

Figure 3: Neuropathology of amyloid plaques from a case GSS $102^{\text {Leu }}$ from original Austrian family.

A: Bielschowsky silver impregnation; amyloid plaques marked with arrows

B: Alcian blue staining 


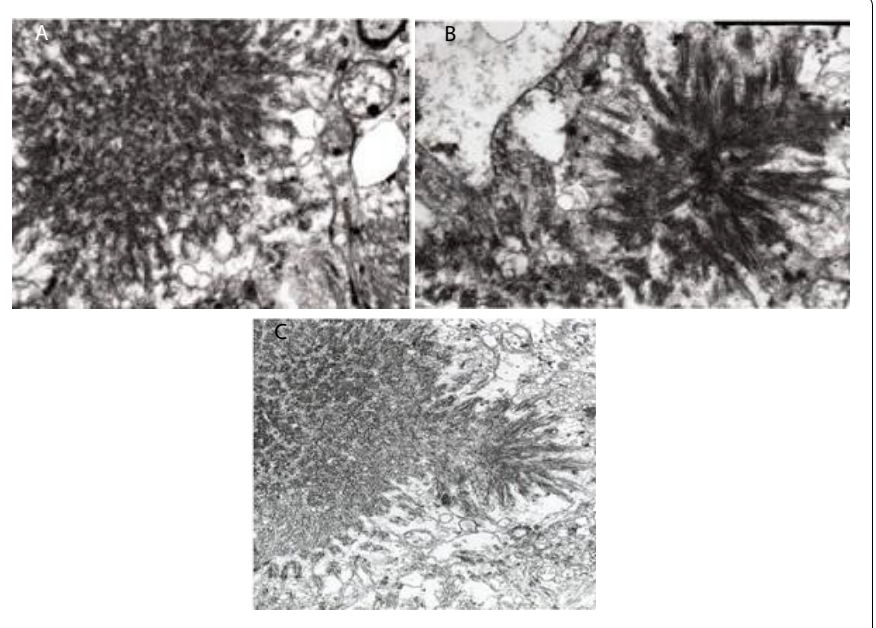

Figure 4: Electron microscopy of GSS plaques

A: unicentric plaque, original magnification, $x 8300$

B: unicentric plaque, original magnification, $x 10000$

$\mathrm{C}$ : a budding of a small plaque from a large core, original magnification, $x 8300$.

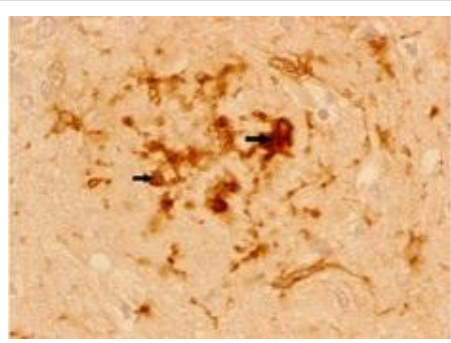

Figure 5: Microglial cells (arrows) within a perimeter of amyloid plaque. Antiferritin abs staining.

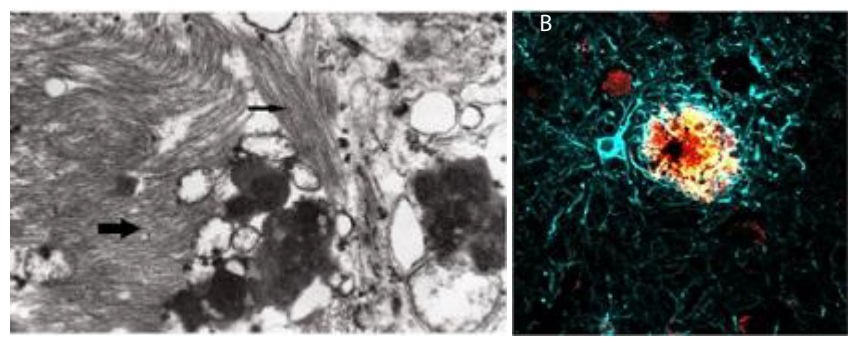

Figure 6: A: Electron microscopic view of a reactive astrocyte around the amyloid plaque, glial filaments are marked with arrows; original magnification, x 10000

$\mathrm{B}$ : confocal laser microscopy view of amyloid plaque (yellow-reddish) surrounded by GFAP-immunopositive astrocytes (blue), courtesy of Dr. Beata Sikorska, Lodz, Poland.

Neuropathology of GSS is characterized by the widespread presence of amyloid plaques in the cerebellum, cortex and subcortical structures (Figure 3). Plaques are either "kuru" plaques - with one core with "spikes", unicentric plaques without "spikes" or multicentric with several overlapping cores (Figure 4). Microglial cells (Figure 5) and reactive astrocytes (Figure 6) are observed within amyloid plaques $[93,94]$. Dystrophic neuritis is abundant (Figure 7). In cases with CJDlike phenotype, a typical spongiform change are seen

Amyloid plaques are labeled with antibodies raised against PrP 90102 and, in much smaller proportion, with antibodies raised against peptide PrP 58-71 [95]. Plaque cores were also strongly stained with Abs raised against residues 95-108, 127-147 and 151-165. Antibodies rose against PrP residues 23-40 (N-terminus) and 220-231 (C-terminus) stained peripheries of plaques as ring-shaped structures. The latter findings indicate that both truncated peptides and full-length PrP may form amyloid fibrils but the truncated fibrils predominated. Another analysis revealed bands of 30,25 and $20 \mathrm{kDa}$ and a single band of 8 $\mathrm{kDa}$, originated exclusively from mutated allele [96]. In addition, $\mathrm{PrP}^{\mathrm{Sc}}$ sensitive for proteinase $\mathrm{K}(\mathrm{PK})$ treatment was found and this species (sPrPsc; "s" from "sensitive") was more abundant that the PK resistant band. Also C-terminal PrP fragments of 16-17 kDa and 12-14 kDa were detected; thus the composition of $\mathrm{PrP}^{\mathrm{Sc}}$ is more heterogeneous than previously thought.

Recently a novel method to detect $\mathrm{PrP}^{\mathrm{Sc}}$ (real-time QUIC [quakinginduced conversion] assay) [97] allow to detected $\mathrm{PrP}^{\mathrm{Sc}}$ in the CSF of $70 \%$ [76.5-100\%] of GSS cases [98].

\section{The codon $105^{\text {Leu }} 129^{\mathrm{Val}}$ mutation}

This mutation was found in 5 GSS families, all from Japan [99106]. The disease manifests as spastic paraparesis with brisk tendom reflexes and the presence of Babinski sign; in terminal stages, patients become teraplegic, demented, with tremor and limb rigidity. Disease starts around 40-50 year of age and the course is long, 6-12 years. $\mathrm{PrP}^{\mathrm{Sc}}$ deposits are encountered mainly in the cerebral cortex and less frequently in striatum. The cerebellum is affected only minimally. In two cases, sparse tau-immunoreactive Neuro Fibrillary Tangles (NFT) composed of paired helical filaments was also observed.

\section{The codon $105^{\mathrm{Ser}} 129^{\mathrm{Val}}$ mutation}

This new mutation in the same codon 105 was described in a 30 -year-old patient with a phenotype reminiscent of frontotemporal dementia [107].
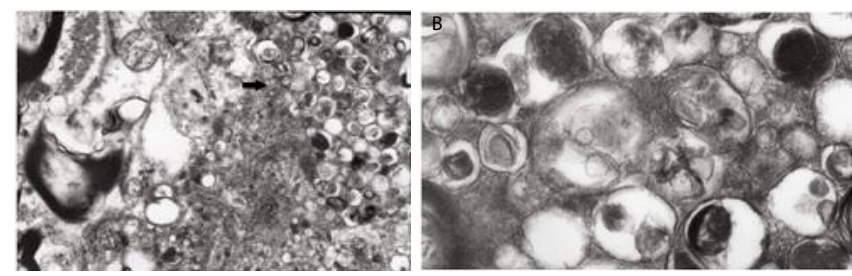

Figure 7: Dystrophic neuritis.

A: a large dystrophic neurite filled with plethora of different subcellular organelles; original magnification, x 8300

B: high power view of the ultrastructure of different subcellular organelles filling a dystrophic neuritis; original magnification, x 33000 .

\section{PK-resistant PrPsc}

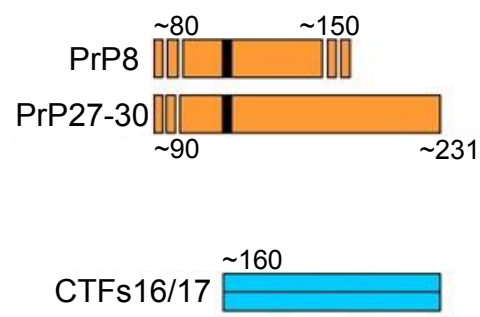

Figure 8: PK-resistant forms of PrP. Those derived from mutant alleles are depicted in orange, those from a wild allele are depicted in blue.Courtesy of Prof. Salvatore Monaco, M.D. Department of Neurosciences, University of Verona, Verona, Italy. 


\section{The codon $117^{\mathrm{Val}} 129^{\mathrm{Val}}$ mutation}

This mutation was discovered in families characterized by dementia but not typical for GSS cerebellar ataxia. Hence, the term "telencephalic type" of GSS was coined $[89,108-116]$ even though the clinical picture is also highly heterogeneous. In an Alsatian family, a generation effect was observed; while in earlier generations only "pure" dementia was observed, in more recent ones a more complex pattern of signs and symptoms was noticed. Amyloid plaques were reactive with antibodies raised against the central region of $\operatorname{PrP}$ while antibodies to the $\mathrm{C}$ - and $\mathrm{N}$-termini of the molecule stained the peripheries of plaques [117]. The amount of $\operatorname{PrP}^{\mathrm{Sc}}$ on Western blot was reported to be negligible [118]. However, a $7 \mathrm{kDa} \operatorname{PrPs}^{\mathrm{sc}}$ was found by Western blot $[117,119,120]$.

Because codon 117 is confined within the sequence STE (STOPtransfer effector) that controls the formation of both transmembrane $\left(\mathrm{PrP}^{\mathrm{Ctm}}\right)$ and secretory $\left(\mathrm{PrP}^{\mathrm{Sec}}\right)$ forms of $\mathrm{PrP}$, [118] that mutation became an ideal target to test the hypothesis that abundance of $\mathrm{PrP}^{\mathrm{Ctm}}$ may exert a pathological effect as suggested by overrepresentation of $\mathrm{PrP}^{\mathrm{Ctm}}$ form in GSS brains. The latter phenomenon suggests that the orientation of $\mathrm{PrP}^{\mathrm{Sc}}$ in regard to the cellular membrane and not merely its presence of this molecule may be important.

\section{The codon $131^{\mathrm{Val}} 129^{\mathrm{Met}}$ mutation}

This mutation was found in only in two families [121,122]. Clinically, it was characterized by changes in personality, dementia, apraxia, cerebellar ataxia, extrapyramidal signs and brisk tendom reflexes. The disease started in the $5^{\text {th }}$ decade and lasted for 9 years. MRI demonstrated cerebral and cerebellar atrophies. Numerous PrPamyloid plaques and diffuse deposits were seen in cerebral cortex, basal ganglia and cerebellum (Figure 10).
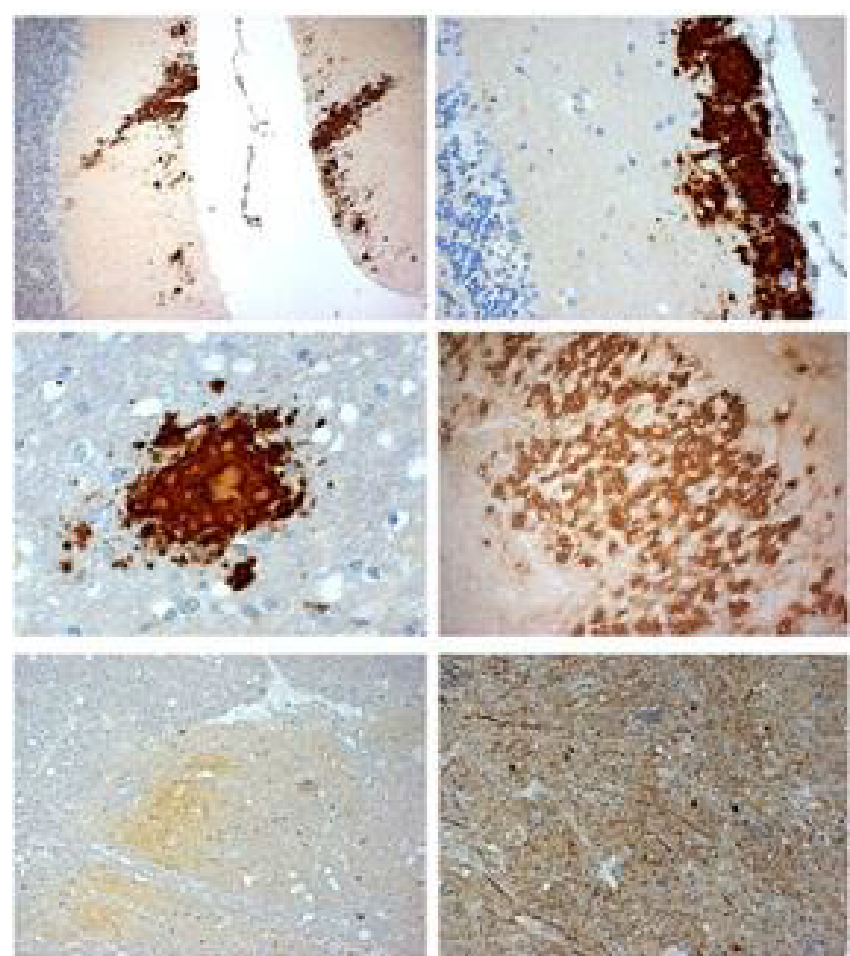

Figure 9: Different forms of amyloid plaques from a case of codon $117^{\mathrm{val}}$ mutation. Courtesy of Dr. Gabor Geza Kovacs, Neurological Institute, Vienna, Austria.

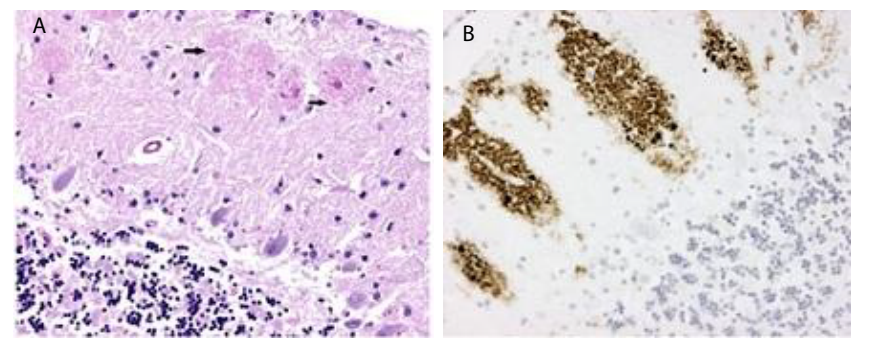

Figure 10: A GSS case with $131^{\mathrm{Val}}$ mutation

A: $H \& E$

B: PrP staining. Courtesy, of Dr. C. Jansen, Klinisch Patholoog Stichting Laboratorium Pathologie Oost-Netherlands.

\section{The codon $145^{\text {stop }}$ mutation}

This mutation was discovered by Kitamoto et al. [123] in a case with spastic paraparesis and progressive severe dementia. Neuropathological examination revealed numerous PrP plaques and $\operatorname{PrP}$ deposits in the wall of brain vessels as well as meningeal vessels (PrP-congophilic angiopathy). Tau-immunoreactive NFT was seen in the neocortex.

\section{The codon $187^{\text {ARg }} 129^{\text {Val }}$ mutation}

This mutation was found in one American family [124]. The age at onset ranged between 33-50 years, and the duration of illness ranged from 8 to 19 years. Clinically, the disease is characterized by dementia, cerebellar ataxia, myoclonic jerks and seizures. Neuropathological examination revealed $\mathrm{PrP}^{\mathrm{Sc}}$ deposits in cerebral cortex of distinct "curly" appearance and laminar pattern. $\operatorname{PrP}$ plaques were absent and spongiform changes were not seen.

\section{The codon $198^{\mathrm{Ser}} 129^{\mathrm{Val}}$ mutation}

This mutation was discovered in two families from Indiana ("Indiana kindred", IK) [125] and in another unrelated family [126]. Patients harboring mutation of the codon 198 are homozygous or heterozygous in respect to Val at codon 129.

The IK is characterized by pyramidal and cerebellar signs, dementia, dysarthria and progressive difficulties of ambulation.Prominent parkinsonian features - i.e., masked facies, bradykinesia, cogwheel rigidity but no tremors are readily detected $[127,128]$. Characteristic alterations of saccadic eye movement [129] may be detected before other signs and symptoms appear. Optokinetic nystagmus and sleep disturbances were seen $[128,129]$. The disease starts between 40 and 70 years of age, and in patients homozygous for $129^{\mathrm{Val}}$, the beginning is approximately 10 years earlier than in heterozygous cases $129^{\text {Val Met }}$ patients. The disease lasts approximately 5 years (from 2 to 12 years), but an accelerated course of 1-2 years is also possible.

PrP-amyloid plaques were seen in the gray matter of neocortex, cerebellum, midbrain, pontine tegmentum and medulla. Plaques were also visible in the striatum, claustrum, the amygdala, the hypothalamus and the thalamus. Some plaques were neuritic. In IK, neurites around plaques contained NFT composed of hyperphosphorylated MAP (microtubulate-associated protein)-tau. Those neurites were also immunoreactive for synaptophysin and $\beta$ APP [130]. Spongiform change was occasionally visible around plaques.

Tagliavini et al. [131] showed that plaques are composed of two species of $\operatorname{PrP}-7$ and $11 \mathrm{kDa}$ spanning $\operatorname{PrP}$ residues $81-150$ and $58-150$, respectively. In contrast, non-fibrillar (pre-amyloid) $\operatorname{PrP}$ is immunolabeled with antibodies raised against residues 23-40 and 220231 [132]. Abs raised against peptide PrP 58-71 stained more plaques 
than in GSS $102^{\text {Leu }}$. In contrast to GSS $102^{\text {Leu }}$, where Abs raised against PrP residues 95-108 stained plaque cores, in IK, those Abs stained the peripheries of plaques but cores are infrequently stained. Abs rose against $\mathrm{PrP}$ residues 23-40 (N-terminus) and 220-231 (C-terminus) stained peripheries of plaques as ring-shaped structures [133].

\section{The codon $202^{\text {Asn }} 129^{\text {Val }}$ mutation}

The duration of illness of a case with $202^{\text {Asn }}$ was 6 years, the disease started in the $8^{\text {th }}$ decade of life and manifested as dementia with cerebellar signs [134-136]. PrP plaques were seen in both brain and the cerebellum; spongiform change was not present. Numerous NFT were visible in the cerebral cortex. A second GSS family was also indentified [45].

\section{The codon $211^{\text {Asp }} 129^{\text {Val Val }}$ and the codon $211^{\text {Gln }} 129^{\text {Met Met }}$ mutation}

This mutation was identified in kindred with ataxia and dementia. Neuropathologically the proband was characterized by numerous plaques surrounded by MAP-tau-immunopositive neuritis [137]. Another mutation - $211^{\text {Gln }} 129^{\text {Met Met }}$ in the same codon was found in two otherwise typical CJD characterized by spongiform change and no plaques. The PrP Western blot revealed co-occurrence of $\mathrm{PrP}^{\mathrm{Sc}}$ type 1 and $2 \mathrm{~A}$ while the GSS case $211^{\text {Asp }}$ was characterized by the presence of otherwise typical for GSS $7 \mathrm{kDa}$ fragment. Biophysical studies suggest that $211^{\text {Asp }} \operatorname{PrP}$ has higher propensity to form oligomers that the $211^{\mathrm{Gln}}$ variant; both peptides appear also to differ in the capacity to form salt bridges [137].

\section{The codon $212^{\text {Pro }} 129^{\text {Met }}$ mutation}

The patient with mutation $212^{\text {Pro }}$ became ill at 60 and the disease lasted for 8 years. Phenotypically, this case demonstrated slurred speech, cerebellar ataxia leading to total incapacitation but not dementia. PrP plaques were visible in both brain and the cerebellum but density of them was the lowest among all GSS families [135]. NMR structure of truncated peptide HuPrP (90-231) revealed different fold from that of the known structures of human $\operatorname{PrP}^{\mathrm{c}}$ [138]. In particular, $\alpha 3$ helix does not exhibit regular helical conformation in two residues $221^{\mathrm{Glu}}$ and $222^{\text {Ser }}$ which results in breaking of $\alpha 3$ into two smaller helices. There is also different orientation of aromatic residues in $\beta 2-\alpha 2$ loop, resulting in the exposure of the hydrophobic surface of $\operatorname{PrP}$ to solvent.

\section{The codon $217^{\text {Arg }} 129^{\mathrm{Val}}$ mutation}

This mutation was described in 2 patients from a Swedish-American family $[110,139,140]$. The disease manifests as psychotic manicdepression disturbances, cognitive alterations leading to dementia, ataxia and parkinsonian features. The neuropathological picture is similar to that of IK; numerous PrP plaques and NFT composed of PHF are visible. $\mathrm{PrP}^{\mathrm{sc}}$ in plaques coexists with $\mathrm{A} \beta$ peptide.

\section{The codon $218^{\text {Asp }} 129^{\text {Val Val }}$ mutation}

This mutation was described in a 61year-old man with nonfluent aphasia, apraxia, agraphia and dysexecutive syndrome, reflex myoclonus and primitive reflexes [141]. Neuropathology consists of uni- and multicentric plaques and robust of MAP-tau-immunoreactive structures, NFT and dystrophic neurites. Western blot for PrP revealed multiple band patterns from $20 \mathrm{kDa}$ to $80 \mathrm{kDa}$.

\section{The codon $227^{\text {STOP }} 129^{\text {Met Val }}$ mutation}

This mutation was described in a 42-year-old woman with slowly progressive hypokinetic rigid syndrome and cognitive impairment

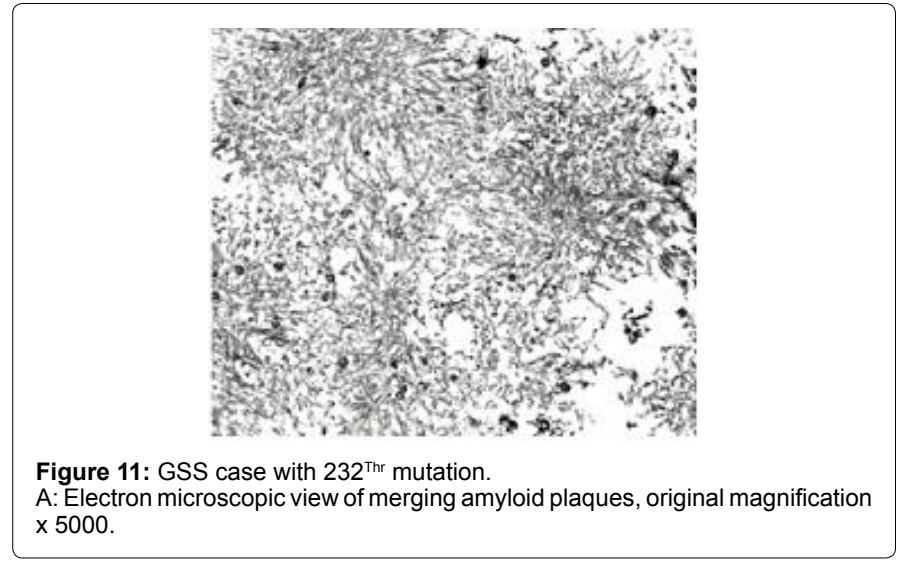

[142]. She also presented tremor in right hand and foot and epileptic seizures. Neuropathologically, she demonstrated numerous multicentric and unicentric plaques, some of them alongside capillaries, numerous MAP-tau-positive tangles in the cerebral cortex and dystrophic neuritis around plaques. $\mathrm{PrP}^{\mathrm{Sc}}$ was typical for GSS, a $7 \mathrm{kDa}$ species.

\section{The codon $232^{\text {Thr }}$ mutation}

This mutation was found by Liberski et al. [142,143] in a case diagnosed earlier as olivopontocerebellar degeneration. The disease started in the $5^{\text {th }}$ decade of live and lasted for 6 years. It manifested as spastic paraparesis and dementia. Numerous PrP plaques were visible in the cerebral and cerebellar cortex and subcortical nuclei (Figure 11); in substantia, nigra Lewy bodies were seen occasionally.

\section{Distinct Patterns of $\operatorname{PrP}^{\mathrm{sc}}$ in CJD and GSS}

Both sporadic and familial forms of CJD are typically characterized by accumulation in the brain of PrP deposits that usually do not stain with amyloid-specific dyes and contain major PK-resistant fragments (for unglycosylated $\mathrm{PrP}$ ) of 21 and/or $19 \mathrm{kDa}$, i.e., corresponding to type 1 and type $2 \mathrm{PrP}^{\mathrm{Sc}}$, respectively. These fragments represent $\mathrm{C}$-terminal parts of the prion protein, with major N-termini at residues 82 and 97 for $\mathrm{PrP}^{\mathrm{sc}}$ type 1 and type 2, respectively. By contrast, most cases of GSS are characterized by amyloid-like deposits containing smaller fragments of $\operatorname{PrP}$ that are truncated both at the $\mathrm{N}$ - and C-termini. For example, in GSS with A117V mutation (GSS $117^{\mathrm{Val}}$ ) the main component of these amyloid deposits is a 7-KDa peptide corresponding to $\mathrm{PrP}$ fragments starting at residues $88 / 90$ and terminating at residues $148 / 152 / 153$. In GSS with F198S mutation (GSS $198^{\text {Ser }}$; Indiana kindred, IK), the main components of amyloid plaques are the 11 and $7 \mathrm{KDa}$ $\operatorname{PrP}$ fragments corresponding to residues approximately 58-150 and $81-150$, respectively [45]. Perhaps the most intriguing situation is presented by GSS cases with P102L mutation (GSS $102^{\mathrm{Leu}}$ ), as this mutation appears to be associated with two distinct phenotypes of GSS diseases. While both phenotypes are characterized by diffuse deposits of $\mathrm{PrP}^{\mathrm{Sc}}$ and $\mathrm{PrP}$ amyloid plaques in the brain, only one of them has spongiform degeneration [144]. The latter type is associated with a major $\mathrm{PrP}^{\mathrm{Sc}}$ fragment of $21-\mathrm{KDa}$ (for the unglycosylated form) and a minor fragment of $8-\mathrm{kDa}$. The first of these fragments (corresponding to residues $\sim 80-231$ ) is similar to type $1 \mathrm{PrP}^{\mathrm{Sc}}$ observed in CJD, whereas the second one (corresponding to residues $\sim 80-150$ ) is similar to those found in other forms of GSS diseases. By contrast, patients without spongiform degeneration show only an $8-\mathrm{kDa} \operatorname{PrP}^{\mathrm{sc}}$ fragment [144] (Figure 9)

Interestingly, while sporadic CJD and many cases of familial CJD have been shown to be transmissible in different animal models, 
attempts to transmit GSS disease have been successful only for cases with the P102L mutation [63]. Furthermore, recent studies revealed that only the GSS $102^{\text {Leu }}$ disease associated with a $21-k D a \operatorname{PrP}^{S c}$ could be transmitted to transgenic mice that carry the P102L mutation. By contrast, no transmissibility of clinical symptoms was observed for the GSS $102^{\text {Leu }}$ disease associated with the $8-\mathrm{kDa}^{\mathrm{PrP}} \mathrm{P}^{\mathrm{sc}}$ fragment [145]. Thus, it is possible that only those prion diseases that are associated with longer PrPsc fragments (containing glycosylation sites and the GPI anchor) are highly transmissible, whereas those associated with $\mathrm{N}$ - and C-truncated shorter fragments are more difficult to transmit (or are not transmissible at all).

\section{Biochemical and Biophysical Effects of Pathogenic Mutations}

Structurally, the normal form of the prion protein consists of the globular C-terminal domain (residues $\sim 125-228$ ) and a $\sim 100$ residue largely unstructured and flexible $\mathrm{N}$-terminal domain (Figure 12). Within the globular domain, there are three $\alpha$-helices and a short antiparallel $\beta$-sheet (2). The distribution of pathogenic mutations is shown in Figure 13, revealing that the vast majority of them congregate within the globular domain. However, a few mutations (P102L, P105L, G114V, A117V, octarepeat expansions) are also found in the flexible $\mathrm{N}$-terminal part. The central question is how these diverse mutations facilitate the conversion of $\operatorname{PrP}^{\mathrm{C}}$ to the disease-associated $\operatorname{Pr}^{\mathrm{Sc}}$ isoform, initiating the pathogenic process that eventually leads to neuronal degeneration. One of the earliest hypotheses was that this occurs by mutation-induced decrese in the global thermodynamic stability of the native $\mathrm{PrP}^{\mathrm{C}}$ isoform. However, experiments revealed that while such

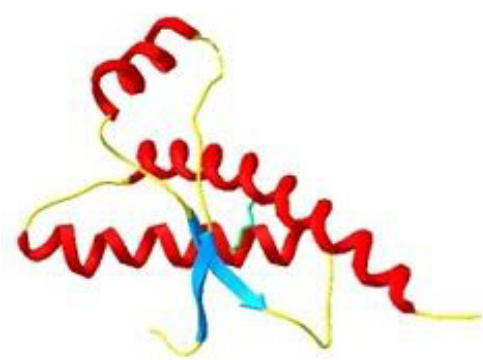

Figure 12: A structureal view of $\mathrm{PrP}^{\mathrm{c}}$.

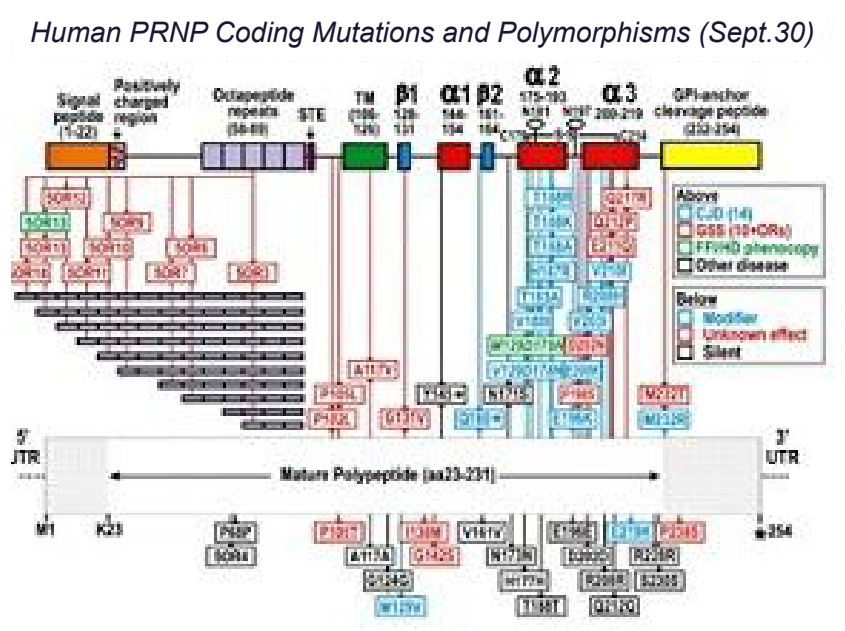

Figure 13: Distribution of all GSS mutations within the PRNP gene. Courtesy of Dr. Paul Brown, Bethesda, Md, USA. destabilization is indeed observed for some pathogenic mutations, many others have a negligible effect on the global thermodynamic stability of PrP. [146,147]. A better correlation was observed in studies probing folding intermediates that may represent direct monomeric precursor in prion protein conversion to the aggregated $\mathrm{PrP}^{\mathrm{Sc}}$ state, as for the vast majority of PrP variants tested mutations linked to familial prion diseases were found to result in a pronounced increase in the stability (and thus population) of these intermediates [148]. However, even in this case, the effect was not universal for all mutant proteins, suggesting that that there might be a number of different mechanisms by which PrP mutations facilitate the pathogenic process.

The lack of a single universal mechanism that could explain pathogenic effects of all known familial $\operatorname{PrP}$ mutations has been further confirmed in numerous structural, biophysical and cellular studies [149]. Overall, it appears that these mutations can produce a host of diverse effects, both at the molecular and cellular level. These include thermodynamic destabilization of the native form of PrP, stabilization of partially structured folding intermediates, altered surface properties of the protein and its interactions with accessory molecules, as well as changes in the metabolic processing and cellular trafficking. There is also no clear correlation between these individual effects and specific phenotypes of prion diseases. It is possible that the phenotypic variability of human prion disorders is largely encoded in distinct structural properties of $\operatorname{PrP}^{\mathrm{Sc}}$ associated with these different phenotypes. However, direct verification of this general hypothesis is difficult as the detailed structure of $\operatorname{PrP}^{\mathrm{Sc}}$ remains unknown.

\section{References}

1. Gambetti P, Puoti G, Zou WQ (2011) Variably protease-sensitive prionopathy: a novel disease of the prion protein. J Mol Neurosci 45: 422-424.

2. Kirschbaum WR (1968) Jakob-Creutzfeldt disease (spastic pseudosclerosisA Jakob; Heidenheim syndrome; subacute spongiform encephalopathy) American Elsevier New York.

3. Meggendorfer F (1930) Klinische und genealogische Beobachtungen bei einem fall von spastischer pseudosklerose Jakobs. Z ges Neurol Psychiatr 128: $337-341$

4. Basler K, Oesch B, Scott M, Westaway D, Wälchli M, et al. (1986) Scrapie and cellular PrP isoforms are encoded by the same chromosomal gene. Cell 46 : 417-428.

5. Miesbauer M, Bamme T, Riemer C, Oidtmann B, Winklhofer KF, et al. (2006) Prion protein-related proteins from zebrafish are complex glycosylated and contain a glycosylphosphatidylinositol anchor. Biochem Biophys Res Commun 341: 218-224.

6. Prusiner SB (1982) Novel proteinaceous infectious particles cause scrapie Science 216: 136-144.

7. Collinge $J(2001)$ Prion diseases of humans and animals: their causes and molecular basis. Annu Rev Neurosci 24: 519-550.

8. Aguzzi A, Polymenidou M (2004) Mammalian prion biology: one century of evolving concepts. Cell 116: 313-327.

9. Cobb NJ, Surewicz WK (2009) Prion diseases and their biochemical mechanisms. Biochemistry 48: 2574-2585.

10. Wang F, Wang X, Yuan CG, Ma J (2010) Generating a prion with bacterially expressed recombinant prion protein. Science 327: 1132-1135.

11. Gambetti P, Cali I, Notari S, Kong Q, Zou WQ, et al. (2011) Molecular biology and pathology of prion strains in sporadic human prion diseases. Acta Neuropathol 121: 79-90.

12. Goldfarb LG, Haltia M, Brown P, Nieto A, Kovanen J, et al. (1991) New mutation in scrapie amyloid precursor gene (at codon 178) in Finnish Creutzfeldt-Jakob kindred. Lancet 337: 425

13. Budka H (1998) Fatal familial insomnia around the world. Introduction. Brain Pathol 8: 553.

14. Kitamoto T, Ohta M, Doh-ura K, Hitoshi S, Terao Y, et al. (1993) Novel missense 
variants of prion protein in Creutzfeldt-Jakob disease or Gerstmann-Sträussler syndrome. Biochem Biophys Res Commun 191: 709-714.

15. Yeo MJ, Lee SH, Lee SY, Jeon YC, Park SJ, et al. (2013) Familial CreutzfeldtJakob disease with a mutation at codon 180 presenting with an atypical phenotype. J Clin Neurosci 20: 180-182.

16. Iwasaki $Y$, Mori K, Ito M, Nagaoka M, leda T, et al. (2011) An autopsied case of V180I Creutzfeldt-Jakob disease presenting with panencephalopathic-type pathology and a characteristic prion protein type. Neuropathology 31: 540-548.

17. Jin K, Shiga Y, Shibuya S, Chida K, Sato Y, et al. (2004) Clinical features of Creutzfeldt-Jakob disease with V180I mutation. Neurology 62: 502-505.

18. Nitrini R, Rosemberg S, Passos-Bueno MR, da Silva LS, lughetti P, et al. (1997) Familial spongiform encephalopathy associated with a novel prion protein gene mutation. Ann Neurol 42: 138-146.

19. Nitrini R, Mendonça RA, Huang N, LeBlanc A, Livramento JA, et al. (2001) Diffusion-weighted MRI in two cases of familial Creutzfeldt--Jakob disease. $J$ Neurol Sci 184: 163-167.

20. Collins S, Boyd A, Fletcher A, Byron K, Harper C, et al. (2000) Novel prion protein gene mutation in an octogenarian with Creutzfeldt-Jakob disease. Arch Neurol 57: 1058-1063.

21. Roeber S, Grasbon-Frodl EM, Windl O, Krebs B, Xiang W, et al. (2008) Evidence for a pathogenic role of different mutations at codon 188 of PRNP. PLoS One 3: e2147.

22. Kotta K, Paspaltsis I, Bostantjopoulou S, Latsoudis H, Plaitakis A, et al. (2006) Novel mutation of the PRNP gene of a clinical CJD case. BMC Infect Dis 6: 169.

23. Schelzke G, Eigenbrod S, Romero C, Varges D, Breithaupt M, et al. (2011) Genetic prion disease with codon 196 PRNP mutation: clinical and pathological findings. Neurobiol Aging 32: 756

24. Goldberg H, Alter M, Kahana E (1979) The Lybian Jewish focus of CreutzfeldtJakob disease: a search for the mode of natural transmission. In: Slow Transmissible diseases of the nervous system. Prusiner SB, Hadlow WJ (Eds.) New York

25. Panegyres PK, Goh JG, Goldblatt J (2012) Codon 200 mutation of the prion gene: genotype-phenotype correlations. J Neurol 259: 2579-2584.

26. Gabizon R, Rosenman H, Meiner Z, Kahana I, Kahana E, et al. (1994) Mutation in codon 200 and polymorphism in codon 129 of the prion protein gene in Libyan Jews with Creutzfeldt-Jakob disease. Philos Trans R Soc Lond B Biol Sci 343: 385-390.

27. Chapman J, Brown P, Goldfarb LG, Arlazoroff A, Gajdusek DC, et al. (1993) Clinical heterogeneity and unusual presentations of Creutzfeldt-Jakob disease in Jewish patients with the PRNP codon 200 mutation. J Neurol Neurosurg Psychiatry 56: 1109-1112.

28. Brown P, Goldfarb LG, Gibbs CJ Jr, Gajdusek DC (1991) The phenotypic expression of different mutations in transmissible familial Creutzfeldt-Jakob disease. Eur J Epidemiol 7: 469-476.

29. Hsiao K, Meiner Z, Kahana E, Cass C, Kahana I, et al. (1991) Mutation of the prion protein in Libyan Jews with Creutzfeldt-Jakob disease. N Engl J Med 324: 1091-1097.

30. Goldfarb LG, Mitrová E, Brown P, Toh BK, Gajdusek DC (1990) Mutation in codon 200 of scrapie amyloid protein gene in two clusters of Creutzfeldt-Jakob disease in Slovakia. Lancet 336: 514-515.

31. Hainfellner JA, Parchi P, Kitamoto T, Jarius C, Gambetti P, et al. (1999) A nove phenotype in familial Creutzfeldt-Jakob disease: prion protein gene E200K mutation coupled with valine at codon 129 and type 2 protease-resistant prion protein. Ann Neurol 45: 812-816.

32. Peoc'h K, Manivet P, Beaudry P, Attane F, Besson G, et al. (2000) Identification of three novel mutations (E196K, V203I, E211Q) in the prion protein gene (PRNP) in inherited prion diseases with Creutzfeldt-Jakob disease phenotype. Hum Mutat 15: 482.

33. Roeber S, Krebs B, Neumann M, Windl O, Zerr I, et al. (2005) CreutzfeldtJakob disease in a patient with an $\mathrm{R} 208 \mathrm{H}$ mutation of the prion protein gene (PRNP) and a 17-kDa prion protein fragment. Acta Neuropathol 109: 443-448.

34. Basset-Leobon C, Uro-Coste E, Peoc'h K, Haik S, Sazdovitch V, et al. (2006) Familial Creutzfeldt-Jakob disease with an R208H-129V haplotype and Kuru plaques. Arch Neurol 63: 449-452.

35. Ripoll L, Laplanche JL, Salzmann M, Jouvet A, Planques B, et al. (1993) A new point mutation in the prion protein gene at codon 210 in Creutzfeldt-Jakob disease. Neurology 43: 1934-1938.

36. Pocchiari M, Salvatore M, Cutruzzolá F, Genuardi M, Allocatelli CT, et al. (1993) A new point mutation of the prion protein gene in Creutzfeldt-Jakob disease. Ann Neurol 34: 802-807.

37. Mouillet-Richard S, Teil C, Lenne M, Hugon S, Taleb O, et al. (1999) Mutation at codon $210(\mathrm{~V} 210 \mathrm{l})$ of the prion protein gene in a North African patient with Creutzfeldt-Jakob disease. J Neurol Sci 168: 141-144.

38. Ladogana A, Almonti S, Petraroli R, Giaccaglini E, Ciarmatori C, et al. (2001) Mutation of the PRNP gene at codon 211 in familial Creutzfeldt-Jakob disease. Am J Med Genet 103: 133-137.

39. Jansen C, Parchi P, Capellari S, Vermeij AJ, Corrado P, et al. (2010) Prion protein amyloidosis with divergent phenotype associated with two novel nonsense mutations in PRNP. Acta Neuropathol 119: 189-197.

40. Shimizu H, Yamada M, Matsubara N, Takano H, Umeda Y, et al. (2009) Creutzfeldt-Jakob disease with an M232R substitution: report of a patient showing slowly progressive disease with abundant plaque-like PrP deposits in the cerebellum. Neuropathology 29: 735-743.

41. Shiga Y, Satoh K, Kitamoto T, Kanno S, Nakashima I, et al. (2007) Two different clinical phenotypes of Creutzfeldt-Jakob disease with a M232R substitution. J Neurol 254: 1509-1517.

42. Hoque MZ, Kitamoto T, Furukawa H, Muramoto T, Tateishi J (1996) Mutation in the prion protein gene at codon 232 in Japanese patients with CreutzfeldtJakob disease: a clinicopathological, immunohistochemical and transmission study. Acta Neuropathol 92: 441-446.

43. Hitoshi S, Nagura H, Yamanouchi H, Kitamoto T (1993) Double mutations at codon 180 and codon 232 of the PRNP gene in an apparently sporadic case of Creutzfeldt-Jakob disease. J Neurol Sci 120: 208-212.

44. Surewicz WK, Apostol MI (2011) Prion protein and its conformational conversion: a structural perspective. Top Curr Chem 305: 135-167.

45. Kong Q, Surewicz WK, Petersen RB, Zou W, Chen SG, et al. (2004) Inherited prion diseases. In: Prion Biology and Diseases. Prusiner SB (ed). Cold Spring Harbor Laboratory Press, New York

46. Vital A, Laplanche JL, Bastard JR, Xiao X, Zou WQ, et al. (2011) A case of Gerstmann-Sträussler-Scheinker disease with a novel six octapeptide repeat insertion. Neuropathol Appl Neurobiol 37: 554-559.

47. Gelpi E, Kovacs GG, Ströbel T, Koperek O, Voigtländer T, et al. (2005) Prion disease with a 144 base pair insertion: unusual cerebellar prion protein immunoreactivity. Acta Neuropathol 110: 513-519.

48. Budka H, Aguzzi A, Brown P, Brucher JM, Bugiani O, et al. (1995) Neuropathological diagnostic criteria for Creutzfeldt-Jakob disease (CJD) and other human spongiform encephalopathies (prion diseases). Brain Pathol 4 459-466.

49. Dimitz L (1913) Bericht der Vereines fur Psychiatrie und Neurologie in Wien (Vereinsjahr 1912/1913), Sitzung vom 11 Juni 1912. Jahrb Psychiatr Neurol 34: 384

50. Gerstmann J (1928) Uber ein noch nicht beschriebenes Reflexphanomen beieiner Erkrankung des zerebellaren Systems. Wien Med Woche 78: 906-908.

51. Gerstmann J, Sträussler E, Scheinker I (1936) Uber eine eigenartige hereditärfamiliäre Erkrankung des Zetralnervensystems. Zugleich ein Beitrag zur Frage des vorzeitigen lokalen Alterns. Z ges Neurol Psychiat 154: 736-762.

52. Liberski PP, Budka H (2004) Gerstmann-Sträussler-Scheinker disease. I. Human diseases. Folia Neuropathol 42 Suppl B: 120-140.

53. VON BRAUNMUHL A (1954) An unusual hereditary familial disease of the central nervous system. Arch Psychiatr Nervenkr Z Gesamte Neurol Psychiatr 191: 419-449.

54. Seitelberger F (1962) Eigenartige familiar-hereditare Krankheit des Zetralnervensystems in einer niederosterreichischen Sippe. Wien Klin Woche 74: 687-691.

55. Seitelberger F (1971) Neuropathological conditions related to neuroaxonal dystrophy. Acta Neuropathol 5: Suppl 5:17-29.

56. Gajdusek DC, Gibbs CJ, Alpers M (1966) Experimental transmission of a Kurulike syndrome to chimpanzees. Nature 209: 794-796.

57. Masters CL, Gajdusek DC, Gibbs CJ Jr (1981) Creutzfeldt-Jakob disease virus 
isolations from the Gerstmann-Sträussler syndrome. With an analysis of the various forms of amyloid plaque deposition in the virus induced spongiform encephalopathies. Brain 104: 559-588.

58. Hainfellner J, Brantner-Inhaler S, Cervenakova L, Brown P, Kitamoto T, et al. (1995) The original Gerstmann-Sträussler-Scheinker family of Austria: divergent clinicopathological phenotypes but constant PrP genotype. Brain Pathol 5: 201-213.

59. Liberski PP, Budka H (1995) Ultrastructural pathology of Gerstmann-SträusslerScheinker disease. Ultrastruct Pathol 19: 23-36.

60. Tateishi J, Kitamoto T, Hashiguchi H, Shii H (1988) Gerstmann-SträusslerScheinker disease: immunohistological and experimental studies. Ann Neurol 24: 35-40.

61. Rosenthal NP, Keesey J, Crandall B, Brown WJ (1976) Familial neurological disease associated with spongiform encephalopathy. Arch Neurol 33: 252-259.

62. Baker HF, Duchen LW, Jacobs JM, Ridley RM (1990) Spongiform encephalopathy transmitted experimentally from Creutzfeldt-Jakob and familial Gerstmann-Sträussler-Scheinker diseases. Brain 113 : 1891-1909.

63. Brown P, Gibbs CJ Jr, Rodgers-Johnson P, Asher DM, Sulima MP, et al. (1994) Human spongiform encephalopathy: the National Institutes of Health series of 300 cases of experimentally transmitted disease. Ann Neurol 35: 513-529.

64. Hsiao K, Baker HF, Crow TJ, Poulter M, Owen F, et al. (1989) Linkage of a prion protein missense variant to Gerstmann-Sträussler syndrome. Nature 338 342-345.

65. Doh-ura K, Tateishi J, Kitamoto T, Sasaki H, Sakaki Y (1990) Creutzfeldt-Jakob disease patients with congophilic kuru plaques have the missense variant prion protein common to Gerstmann-Sträussler syndrome. Ann Neurol 27: 121-126.

66. Ishizawa K, Komori T, Shimazu T, Yamamoto T, Kitamoto T, et al. (2002) Hyperphosphorylated tau deposition parallels prion protein burden in a case of Gerstmann-Sträussler-Scheinker syndrome P102L mutation complicated with dementia. Acta Neuropathol 104: 342-350.

67. Konaka K, Kaido M, Okuda Y, Aoike F, Abe K, et al. (2000) Proton magnetic resonance spectroscopy of a patient with Gerstmann-Straussler-Scheinker disease. Neuroradiology 42: 662-665.

68. Muramoto T, Tanaka T, Kitamoto N, Sano C, Hayashi Y, et al. (2000) Analyses of Gerstmann-Sträussler syndrome with 102Leu219Lys using monoclonal antibodies that specifically detect human prion protein with $219 \mathrm{Glu}$. Neurosci Lett, 288: 179-182.

69. Sasaki K, Doh-ura K, Furuta A, Nakashima S, Morisada Y, et al. (2003) Neuropathological features of a case with schizophrenia and prion protein gene P102L mutation before onset of Gerstmann-Sträussler-Scheinker disease. Acta Neuropathol 106: 92-96.

70. Sugai F, Nakamori M, Nakatsuji Y, Abe K, Sakoda S (2000) [A case of Gerstmann-Sträussler-Scheinker syndrome (P102L) accompanied by optic atrophy]. Rinsho Shinkeigaku 40: 926-928.

71. Tanaka Y, Minematsu K, Moriyasu H, Yamaguchi T, Yutani C, et al. (1997) A Japanese family with a variant of Gerstmann-Sträussler-Scheinker disease. J Neurol Neurosurg Psychiatry 62: 454-457.

72. Brown P, Goldfarb LG, Brown WT, Goldgaber D, Rubenstein R, et al. (1991) Clinical and molecular genetic study of a large German kindred with GerstmannSträussler-Scheinker syndrome. Neurology 41: 375-379.

73. Goldgaber D, Goldfarb LG, Brown P, Asher DM, Brown WT, et al. (1989) Mutations in familial Creutzfeldt-Jakob disease and Gerstmann-SträusslerScheinker's syndrome. Exp Neurol 106: 204-206.

74. Boellaard JW, Schlote W (1980) Subakute spongiforme Encephalopathie mit multiformer Plaquebildung. „Eigenartige familiar-hereditare Kranknheit des Zentralnervensystems [spino-cerebellare Atrophie mit Demenz, Plaques and plaqueähnlichen im Klein- and Grosshirn“(Gerstmann, Sträussler, Scheinker)]. Acta Neuropathol (Berl) 49: 205-212.

75. Doerr-Schott J, Kitamoto T, Tateishi J, Boellaard JW, Heldt N, et al. (1990) Technical communication. Immunogold light and electron microscopic detection of amyloid plaques in transmissible spongiform encephalopathies. Neuropathol Appl Neurobiol 16: 85-89.

76. Schlote W, Boellaard JW, Schumm F, Stöhr M (1980) Gerstmann-SträusslerScheinker's disease. Electron-microscopic observations on a brain biopsy. Acta Neuropathol 52: 203-211.

77. Schumm F, Boellaard JW, Schlote W, Stöhr M (1981) Morbus Gerstmann-
Sträussler-Scheinker. The Sch. family-a report of three cases (author's transl) Arch Psychiatr Nervenkr 230: 179-196.

78. Goldhammer Y, Gabizon R, Meiner Z, Sadeh M (1993) An Israeli family with Gerstmann-Sträussler-Scheinker disease manifesting the codon 102 mutation in the prion protein gene. Neurology 43: 2718-2719.

79. Majtényi C, Brown P, Cervenáková L, Goldfarb LG, Tateishi J (2000) A three-sister sibship of Gerstmann-Sträussler-Scheinker disease with a CJD phenotype. Neurology 54: 2133-2137.

80. Kulczycki J, Collinge J, Lojkowska W, Parnowski T, Wierzba-Bobrowicz T (2001) Report on the first polish case of the Gerstmann-Sträussler-Scheinker syndrome. Folia Neuropathol 39: 27-31.

81. Cameron E, Crawford AD (1974) A familial neurological disease complex in a Bedfordshire community. J R Coll Gen Pract 24: 435-436.

82. Collinge J, Harding AE, Owen F, Poulter M, Lofthouse R, et al. (1989) Diagnosis of Gerstmann-Sträussler syndrome in familial dementia with prion protein gene analysis. Lancet 2: 15-17

83. Barbanti P, Fabbrini G, Salvatore M, Petraroli R, Cardone F, et al. (1996) Polymorphism at codon 129 or codon 219 of PRNP and clinical heterogeneity in a previously unreported family with Gerstmann-Sträussler-Scheinker disease (PrP-P102L mutation). Neurology 47: 734-741.

84. Bianca M, Bianca S, Vecchio I, Raffaele R, Ingegnosi C, et al. (2003) Gerstmann-Sträussler-Scheinker disease with P102L-V129 mutation: a case with psychiatric manifestations at onset. Ann Genet 46: 467-469.

85. De Michele G, Pocchiari M, Petraroli R, Manfredi M, Caneve G, et al. (2003) Variable phenotype in a P102L Gerstmann-Sträussler-Scheinker Italian family. Can J Neurol Sci 30: 233-236.

86. Kretzschmar HA, Honold G, Seitelberger F, Feucht M, Wessely P, et al. (1991) Prion protein mutation in family first reported by Gerstmann, Sträussler, and Scheinker. Lancet 337: 1160.

87. Kitamoto T, Tateishi J (1988) Immunohistochemical confirmation of CreutzfeldtJakob disease with a long clinical course with amyloid plaque core antibodies. Am J Pathol 131: 435-443.

88. Imaiso Y, Mitsuo K (1998) Gerstmann-Sträussler-Scheinker syndrome with a Pro102Leu mutation in the prion protein gene and atypical MRI findings, hyperthermia, tachycardia, and hyperhidrosis. Rinsho Shinkeigaku 38: 920925

89. Doh-ura K, Tateishi J, Sasaki H, Kitamoto T, Sakaki Y (1989) Pro----leu change at position 102 of prion protein is the most common but not the sole mutation related to Gerstmann-Sträussler syndrome. Biochem Biophys Res Commun 163: 974-979.

90. Miyazono M, Kitamoto T, Iwaki T, Tateishi J (1992) Colocalization of prion protein and beta protein in the same amyloid plaques in patients with GerstmannSträussler syndrome. Acta Neuropathol 83: 333-339.

91. Young K, Jones CK, Piccardo P, Lazzarini A, Golbe LI, et al. (1995) GerstmannSträussler-Scheinker disease with mutation at codon 102 and methionine at codon 129 of PRNP in previously unreported patients. Neurology 45: 11271134.

92. Young K, Clark HB, Piccardo P, Dlouhy SR, Ghetti B (1997) GerstmannSträussler-Scheinker disease with the PRNP P102L mutation and valine at codon 129. Brain Res Mol Brain Res 44: 147-150.

93. Guiroy DC, Wakayama I, Liberski PP, Gajdusek DC (1994) Relationship of microglia and scrapie amyloid-immunoreactive plaques in kuru, CreutzfeldtJakob disease and Gerstmann-Sträussler syndrome. Acta Neuropathol 87 526-530.

94. Barcikowska M, Liberski PP, Boellaard JW, Brown P, Gajdusek DC, et al. (1993) Microglia is a component of the prion protein amyloid plaque in the GerstmannSträussler-Scheinker syndrome. Acta Neuropathol 85: 623-627.

95. Piccardo P, Ghetti B, Dickson DW, Vinters HV, Giaccone G, et al. (1995) Gerstmann-Sträussler-Scheinker disease (PRNP P102L): amyloid deposits are best recognized by antibodies directed to epitopes in PrP region 90-165. J Neuropathol Exp Neurol 54: 790-801.

96. Monaco S, Fiorini M, Farinazzo A, Ferrari S, Gelati M, et al. (2012) Allelic origin of protease-sensitive and protease-resistant prion protein isoforms in Gerstmann-Sträussler-Scheinker disease with the P102L mutation. PLoS One 7: e32382.

97. McGuire LI, Peden AH, Orrú CD, Wilham JM, Appleford NE, et al. (2012) Rea 
time quaking-induced conversion analysis of cerebrospinal fluid in sporadic Creutzfeldt-Jakob disease. Ann Neurol 72: 278-285.

98. Sano K, Satoh K, Atarashi R, Takashima H, Iwasaki Y, et al. (2013) Early detection of abnormal prion protein in genetic human prion diseases now possible using real-time QUIC assay. PLoS One 8: e54915.

99. Amano N, Yagishita S, Yokoi S, Itoh Y, Kinoshita J, et al. (1992) GerstmannSträussler syndrome--a variant type: amyloid plaques and Alzheimer's neurofibrillary tangles in cerebral cortex. Acta Neuropathol 84: 15-23.

100. Itoh Y, Yamada M, Hayakawa M, Shozawa T, Tanaka J, et al. (1994) A variant of Gerstmann-Sträussler-Scheinker disease carrying codon 105 mutation with codon 129 polymorphism of the prion protein gene: a clinicopathological study. J Neurol Sci 127: 77-86.

101. Kitamoto T, Amano N, Terao Y, Nakazato Y, Isshiki T, et al. (1993) A new inherited prion disease (PrP-P105L mutation) showing spastic paraparesis. Ann Neurol 34: 808-813.

102. Kubo M, Nishimura T, Shikata E, Kokubun Y, Takasu T (1995) A case of variant Gerstmann-Sträussler-Scheinker disease with the mutation of codon P105L. Rinsho Shinkeigaku 35: 873-877.

103. Nakazato Y, Ohno R, Negishi T, Hamaguchi K, Arai E (1991) An autopsy case of Gerstmann-Sträusser-Scheinker's disease with spastic paraplegia as its principal feature. Rinsho Shinkeigaku 31: 987-992.

104. Yamada M, Itoh Y, Fujigasaki H, Naruse S, Kaneko K, et al. (1993) A missense mutation at codon 105 with codon 129 polymorphism of the prion protein gene in a new variant of Gerstmann-Sträussler-Scheinker disease. Neurology 43 2723-2724.

105. Yamada M, Itoh Y, Inaba A, Wada Y, Takashima M, et al. (1999) An inherited prion disease with a PrP P105L mutation: clinicopathologic and PrP heterogeneity. Neurology 53: 181-188.

106. Yamazaki M, Oyanagi K, Mori O, Kitamura S, Ohyama M, et al. (1999) Varian Gerstmann-Sträussler syndrome with the $\mathrm{P} 105 \mathrm{~L}$ prion gene mutation: an unusual case with nigral degeneration and widespread neurofibrillary tangles. Acta Neuropathol 98: 506-511.

107. Tunnell E, Wollman R, Mallik S, Cortes CJ, Dearmond SJ, et al. (2008) A nove PRNP-P105S mutation associated with atypical prion disease and a rare PrPSc conformation. Neurology 71: 1431-1438.

108. Heldt N, Boellaard JW, Brown P, Cervenákova L, Doerr-Schott J, et al. (1998) Gerstmann-Sträussler-Scheinker disease with $\mathrm{A} 117 \mathrm{~V}$ mutation in a second French-Alsatian family. Clin Neuropathol 17: 229-234.

109. Heldt N, Floquet J, Warter JM, Steinmetz WG, Weber M, et al. (1983) Syndrome de Gerstmann-Sträussler-Scheinker: Neuropathologie de trois cas dans une famille alsacienne. In: Court LA, Cathala F (Eds.). Virus non conventionnels et affections du systeme nerveux central. Masson Paris: 290-297.

110. Hsiao K, Dlouhy SR, Farlow MR, Cass C, Da Costa M, et al. (1992) Mutan prion proteins in Gerstmann-Sträussler-Scheinker disease with neurofibrillary tangles. Nat Genet 1: 68-71.

111. Mallucci GR, Campbell TA, Dickinson A, Beck J, Holt M, et al. (1999) Inherited prion disease with an alanine to valine mutation at codon 117 in the prion protein gene. Brain 122 : 1823-1837.

112. Mastrianni JA, Curtis MT, Oberholtzer JC, Da Costa MM, DeArmond S, et al (1995) Prion disease (PrP-A117V) presenting with ataxia instead of dementia. Neurology 45: 2042-2050.

113. Mohr M, Tranchant C, Steinmetz G, Floquet J, Grignon Y, et al. (1999) Gerstmann-Sträussler-Scheinker disease and the French-Alsatian A117V variant. Clin Exp Pathol 47: 161-175.

114. Tranchant C, Doh-Ura K, Steinmetz G, Chevalier Y, Kitamoto T, et al. (1991) [Mutation of codon 117 of the prion gene in Gerstmann-Sträussler-Scheinker disease]. Rev Neurol (Paris) 147: 274-278.

115. Tranchant C, Doh-ura K, Warter JM, Steinmetz G, Chevalier Y, et al. (1992) Gerstmann-Sträussler-Scheinker disease in an Alsatian family: clinical and genetic studies. J Neurol Neurosurg Psychiatry 55: 185-187.

116. Tranchant C, Sergeant N, Wattez A, Mohr M, Warter JM, et al. (1997) Neurofibrillary tangles in Gerstmann-Sträussler-Scheinker syndrome with the A117V prion gene mutation. J Neurol Neurosurg Psychiatry 63: 240-246.

117. Tagliavini F, Lievens P.M-J, Tranchant C, Warter JM, Mohr M, et al., (2001) A 7-kDa prion protein (PrP) fragment, an integral component of the PrP region required for infectivity, is the major amyloid protein in Gerstmann-SträusslerScheinker disease A117V. J Biol Chem 276: 6009-6015.
118. Hegde RS, Mastrianni JA, Scott MR, DeFea KA, Tremblay P, et al. (1998) A transmembrane form of the prion protein in neurodegenerative disease. Science 279: 827-834

119. Ghetti B, Bugiani O, Tagliavini F, Piccardo P (2003) Gerstmann-SträusslerScheinker disease In: Neurodegeneration: The Molecular Pathology of Dementia and Movement Disorders. Dickson D (Ed). ISN Neuropath Press Basel: 318-325

120. Piccardo P, Liepnieks JJ, William A, Dlouhy SR, Farlow MR, et al. (2001) Prion proteins with different conformations accumulate in Gerstmann-SträusslerScheinker disease caused by A117V and F198S mutations. Am J Pathol 158 : 2201-2207

121. Panegyres PK, Toufexis K, Kakulas BA, Cernevakova L, Brown P, et al. (2001) A new PRNP mutation (G131V) associated with Gerstmann-SträusslerScheinker disease. Arch Neurol 58: 1899-1902.

122. Jansen C, Parchi P, Capellari S, Strammiello R, Dopper EG, et al. (2011) A second case of Gerstmann-Sträussler-Scheinker disease linked to the G131V mutation in the prion protein gene in a Dutch patient. J Neuropathol Exp Neurol 70: 698-702

123. Kitamoto T, lizuka R, Tateishi J (1993) An amber mutation of prion protein in Gerstmann-Sträussler syndrome with mutant PrP plaques. Biochem Biophys Res Commun 192: 525-531.

124. Bütefisch CM, Gambetti P, Cervenakova L, Park KY, Hallett M, et al. (2000) Inherited prion encephalopathy associated with the novel PRNP H187R mutation: a clinical study. Neurology 55: 517-522.

125.Dlouhy SR, Hsiao K, Farlow MR, Foroud T, Conneally PM, et al. (1992) Linkage of the Indiana kindred of Gerstmann-Sträussler-Scheinker disease to the prion protein gene. Nat Genet 1: 64-67.

126. Mirra SS, Young K, Gearing M, Jones R, Evatt ML, et al. (1997) Coexistence of prion protein (PrP) amyloid, neurofibrillary tangles and Lewy bodies in Gerstmann-Sträussler-Scheinker disease with prion gene (PRNP) mutation F198S. Brain Pathol 7: 1378.

127.Farlow MR, Tagliavini F, Bugiani O, Ghetti B (1991) Gerstmann-SträusslerScheinker disease. In: Vinken PJ, Bruyn GW, Klawans HL (Eds.). Hereditary Neuropathies and Spinocerebellar Atrophies. Elsevier Science Publishers, Amsterdam: 619-633.

128. Farlow MR, Yee RD, Dlouhy SR, Conneally PM, Azzarelli B, et al. (1989) Gerstmann-Sträussler-Scheinker disease. I. Extending the clinical spectrum. Neurology 39: 1446-1452.

129. Yee RD, Farlow MR, Suzuki DA, Betelak KF, Ghetti B (1992) Abnormal eye movements in Gerstmann-Sträussler-Scheinker disease. Arch Ophthalmo 110: $68-74$

130. Bugiani O, Giaccone G, Verga L, Pollo B, Frangione B, et al. (1993) ?PP participates in PrP-amyloid plaques of Gerstmann-Straussler-Scheinker disease, Indiana kindred. J Neuropathol Exp Neurol 52: 64-70.

131. Tagliavini F, Prelli F, Porro M, Rossi G, Giaccone G, et al. (1994) Amyloid fibrils in Gerstmann-Sträussler-Scheinker disease (Indiana and Swedish kindreds) express only PrP peptides encoded by the mutant allele. Cell 79: 695-703.

132. Ghetti B, Tagliavini F, Giaccone G, Bugiani O, Frangione B, et al. (1994) Familial Gerstmann-Sträussler-Scheinker disease with neurofibrillary tangles. Mol Neurobiol 8: 41-48.

133. Giaccone G, Verga L, Bugiani O, Frangione B, Serban D, et al. (1992) Prion protein preamyloid and amyloid deposits in Gerstmann-Sträussler-Scheinker disease, Indiana kindred. Proc Natl Acad Sci U S A 89: 9349-9353.

134. Ghetti B, Piccardo P, Lievens PMJ, Young K, Pocchiari M, et al. (1998) Phenotypic and prion protein (PrP) heterogeneity in Gerstmann-SträusslerScheinker disease (GSS) with a proline to a leucine mutation at PRNP residue 102. In: The 6th International Conference on Alzheimer's disease and Related Disorders, Amsterdam, 18-23 July. Neurobiol Aging 19: 298.

135. Piccardo P, Dlouhy SR, Lievens PMJ, Young K, Bird TD, et al. (1998) phenotypic variability of Gerstmann-Sträussler-Scheinker disease is associated with prion protein heterogeneity. J Neuropathol Exp Neurol 57: 979-988.

136. Young K, Piccardo P, Kish SJ, Ang LC, Dlouhy S, et al. (1998) GerstmannSträussler-Scheinker disease (GSS) with a mutation at prion protein ( $\operatorname{PrP}$ ) residue 212. W: The 74th Annual Meeting of the American Association of Neuropathologists Inc, Minneapolis, Minnesota, June 18-21. J Neuropathol Exp Neurol 57: 518 
137.Peoc'h K, Levavasseur E, Delmont E, De Simone A, Laffont-Proust I, et al. (2012) Substitutions at residue 211 in the prion protein drive a switch between CJD and GSS syndrome, a new mechanism governing inherited neurodegenerative disorders. Hum Mol Genet 21: 5417-5428.

138. Ilc G, Giachin G, Jaremko M, Jaremko $\AA \square$, Benetti F, et al. (2010) NMR structure of the human prion protein with the pathological Q212P mutation reveals unique structural features. PLoS One 5: e11715.

139. Ghetti B, Dlouhy SR, Giaccone G, Bugiani O, Frangione B, et al. (1995) Gerstmann-Sträussler-Scheinker disease and the Indiana kindred. Brain Pathol 5: 61-75.

140. Ikeda S, Yanagisawa N, Glenner GG, Allsop D (1992) Gerstmann-SträusslerScheinker disease showing ß-protein amyloid deposits in the peripheral regions of PrP -immunoreactive amyloid plaques. Neurodegeneration 1: 281 288.

141. Alzualde A, Indakoetxea B, Ferrer I, Moreno F, Barandiaran M, et al. (2010) A novel PRNP Y218N mutation in Gerstmann-Sträussler-Scheinker disease with neurofibrillary degeneration. J Neuropathol Exp Neurol 69: 789-800.

142. Bratosiewicz-Wasik J, Wasik TJ, Liberski PP (2004) Molecular approaches to mechanisms of prion diseases. Folia Neuropathol 42 Suppl A: 33-46.

143. Liberski PP, Bratosiewicz J, Barcikowska M, Cervenakova L, Marczewska M, et al. (2000) A case of sporadic Creutzfeldt-Jakob disease with Gerstmann-
Sträussler-Scheinker phenotype but no alterations in the PRNP gene. Acta Neuropathol (Berl) 100: 233-234.

144. Parchi P, Chen SG, Brown P, Zou W, Capellari S, et al. (1998) Different patterns of truncated prion protein fragments correlate with distinct phenotypes in P102L Gerstmann-Sträussler-Scheinker disease. Proc Natl Acad Sci U S A 95: 8322-8327.

145. Piccardo P, Manson JC, King D, Ghetti B, Barron RM (2007) Accumulation of prion protein in the brain that is not associated with transmissible disease. Proc Natl Acad Sci U S A 104: 4712-4717.

146. Liemann S, Glockshuber R (1999) Influence of amino acid substitutions related to inherited human prion diseases on the thermodynamic stability of the cellular prion protein. Biochemistry 38: 3258-3267.

147. Swietnicki W, Petersen RB, Gambetti P, Surewicz WK (1998) Familia mutations and the thermodynamic stability of the recombinant human prion protein. J Biol Chem 273: 31048-31052.

148. Apetri AC, Surewicz K, Surewicz WK (2004) The effect of disease-associated mutations on the folding pathway of human prion protein. J Biol Chem 279 18008-18014.

149.van der Kamp MW, Daggett $V$ (2009) The consequences of pathogenic mutations to the human prion protein. Protein Eng Des Sel 22: 461-468.
This article was originally published in a special issue, Quantitive Genetics/ Molecular Genetics handled by Editor(s). Dr. Ajoy Mandal, Eastern Regiona Station of National Dairy Research Institute, India 